\title{
Influence of Molybdenum on Microstructure and Pitting Corrosion Behavior of Solution- Treated Duplex Stainless Steel in a Lithium Chloride Solution
}

\author{
Stephania Cappellari de Rezende ${ }^{\circledR}$, Isabela Dainezi ${ }^{(\mathbb{}}{ }^{\circledR}$, Raíra Chefer Apolinario $^{a}{ }^{\mathbb{D}}$, \\ Lucíola Lucena de Sousa $^{a}{ }^{\circledR}$, Neide Aparecida Mariano ${ }^{a} * \mathbb{1}$ \\ ${ }^{a}$ Universidade Federal de Alfenas - UNIFAL, Campus Avançado de Poços de Caldas, Rod. José Aurélio \\ Vilela, BR 267 - Km 533, Cidade Universitária, Poços de Caldas, 377015-400, MG, Brasil
}

Received: February 15, 2019; Revised: July 03, 2019; Accepted: August 15, 2019

\begin{abstract}
With technological advances in the several areas of knowledge, the constant search for materials with characteristics that meet certain applications has been growing, especially in the chemical and petrochemical industries, where materials capable of withstanding the conditions of corrosion in aggressive environments are required. The aim of this paper was to analyze the influence of the alloy element molybdenum on the microstructure and the resistance to corrosion of two duplex stainless steels identified as A (with molybdenum) and B (without molybdenum), after solution-treated under the following conditions: heating at $1100^{\circ} \mathrm{C}$ for 30,120 and 240 minutes. The steels were characterized by SEM, EDS, DRX and microhardness. The rise in solution treatment time fostered an increase in the volumetric fraction of the ferrite phase, in both steels. The solution treatment at $1100^{\circ} \mathrm{C}$ for 120 minutes, for steels A and B, provided good resistance to pit corrosion, as well as the development of a passivating film in the solution of lithium chloride (120,000 ppm of chloride ions).
\end{abstract}

Keywords: Duplex stainless steel, solution-treated, corrosion.

\section{Introduction}

Duplex stainless steel (DSS) is an alternative for industries that operate in highly corrosive environments, including the chemical, petrochemical, nuclear, maritime, paper and cellulose industries, petroleum refineries and desalination plants, since it possesses optimal mechanical properties, such as high toughness and mechanical resistance, weldability, in addition to high resistance to corrosion ${ }^{1-3}$.

These characteristics are achieved due to the low levels of carbon and a two-phase microstructure composed of ferrite $(\alpha)$ and austenite $(\gamma)$ in levels balanced by elements of stabilizing ferrite (chromium, molybdenum, tungsten, niobium, titanium and silicon) and austenite (carbon, nickel, nitrogen, copper and manganese) alloys ${ }^{4}$.

The microstructure is formed from the solidification process. Starting from the liquid state, an entirely ferritic microstructure is formed (delta-ferrite), and with the cooling process a partial transformation into austenite occurs $(\mathrm{L} \rightarrow$ $\mathrm{L}+\delta \rightarrow \delta+\gamma)^{5}$.

Austenite is formed between 650 and $1200^{\circ} \mathrm{C}$, by the nucleation and growth process. Firstly, the precipitation of austenite with Widmanstatten morphology occurs both inside and in the contours of the grains in the ferrite phase. Then, the precipitation of austenite in the form of islands of intragranular lamellae occurs ${ }^{6-11}$.

The partition of the alloying elements between the ferrite and austenite phases occurs by the diffusion process, the partition coefficient being highly dependent on the cooling

*e-mail: neideaparecidamariano@gmail.com rate to which the material is submitted ${ }^{3-4}$. The slow cooling rate favors the partition of the alloy elements between the two phases $(\alpha / \gamma)$, while the faster cooling rate fosters the inhibition of the alloy elements ${ }^{4}$.

The excessive addition of alloy elements and their diffusivity in ferrite make the steel unstable, fostering the precipitation of intermetallic phases (sigma- $\sigma$, chi- $\chi$, secondary austenite- $\gamma_{2}$, alpha prime- $\alpha$ '), carbides and chromium nitrides, when exposed to temperatures between $300-1000^{\circ} \mathrm{C}$, in processes such as thermal treatments, welding, plastic deformation and aging $^{5-6}$. These phases are fragilizing and affect the mechanical properties, besides reducing the resistance to corrosion ${ }^{7}$.

The alloy element molybdenum is a stabilizer of the ferrite phase and its addition to duplex stainless steel (DSS) is usually of around $4 \%$. Higher rates foster the precipitation of intermetallic phases (chi- $\chi$ and sigma- $\sigma$ ), especially when exposed to high temperatures ${ }^{12-20}$.

Molybdenum and chromium raise the resistance to crevice and pit corrosion and are capable of stabilizing the passive film in media containing chlorine ions, increasing the possibilities of their use ${ }^{12-18}$. Pit corrosion is influenced by the aggressive concentration of ions, by temperature, composition of the alloy and presence of the sigma- $\sigma$ phase ${ }^{21-25}$.

The aim of this work was to analyze the influence of the alloy element Mo on DSS microstructure and resistance to corrosion after solubilization treatments.

\section{Materials and Methods}

The chemical compositions obtained by inductively coupled plasma-atomic emission spectrometer (ICP/AES) for these 
steels are shown in Table 1. The samples were solubilised at $1100^{\circ} \mathrm{C}$ for 30,120 and 240 minutes, and cooled in water until reaching room temperature.

The samples were analyzed by scanning electron microscopy (SEM), according to the ASTM E3-11 standard, and the semi-quantitative microanalysis of the phases was obtained by energy-dispersive spectroscopy (EDS), after electrolytic etching in $10 \%$ oxalic acid and current density of $1 \mathrm{~A} / \mathrm{cm}^{2}$. $\mathrm{X}$-ray diffraction (XRD) analysis was performed with $\mathrm{Cu}$ $\mathrm{K} \alpha$ radiation, in a range of $2 \theta$ from $10^{\circ}$ to $90^{\circ}$, with a step of $0.02^{\circ}$ for $2 \mathrm{~s} / \mathrm{step}$.

The quantitative stereology analysis was undertaken with the help of the Axio Vision 4.8.2 SP2 software connected to an image analyzer. Ten fields were analyzed in order to calculate the distribution of phases in each sample, and the quantification was based on the difference in the colors present in the captured images.

The thermal analysis was performed using differential scanning calorimetry (DSC) and thermogravimetry (TG). The samples were submitted to heating from $30^{\circ} \mathrm{C}$ to $1200^{\circ} \mathrm{C}$, at a heating rate of $10^{\circ} \mathrm{C} / \mathrm{min}$, under a synthetic air atmosphere.

The corrosion behavior was evaluated by the cyclic potentiodynamic polarization method using a potentiostat Metrohm model Autolab/PGSTART 302 connected to a typical electrochemical cell with a saturated calomel electrode (SCE) used as a reference electrode, a platinum plate employed as counter-electrode and the working electrode made from the steel under study. Electrochemical measurements were performed in triplicate for each condition. An aerated solution of lithium chloride ( $\mathrm{LiCl}$ ) with $120,000 \mathrm{ppm}$ of chloride ions at room temperature was used.

After immersion in the solution, the samples were subjected to conditions of open circuit potential (OCP) for 1200 seconds, and this period of time was enough to stabilize the potential ${ }^{26,27}$. These tests were performed in triplicate and showed reproducibility of the results obtained. The potentiodynamic curves were measured at a potential scan rate of $1 \mathrm{mV} / \mathrm{s}$ with reversion of the direction when the anodic current density of $10^{-3} \mathrm{~A} / \mathrm{cm}^{2}$ was reached. The microhardness (HV) test was performed with a load of $0.1 \mathrm{kgf}$ and printing time of 15 seconds.

\section{Results and Discussions}

The micrographs of the duplex stainless steels A and B (DSSA and DSSB), in the conditions as received, obtained by scanning electron microscopy (SEM), are presented in Figure 1. It is noted that the microstructure is composed of austenite $(\gamma)$ phases in the shape of elongated islands dispersed in the ferritic $(\alpha)$ matrix and free of precipitates.

The duplex stainless steels $\mathrm{A}$ and $\mathrm{B}$ were solution-treated at $1100^{\circ} \mathrm{C}$ for 30,120 and 240 minutes, and cooled in water. The micrographs are shown in Figures 2 and 3, respectively. In both steels it was observed that the increase in the time of solution treatment fostered an increase in the ferrite $(\alpha)$ phase over the austenite $(\gamma)$ phase, also observed in the quantitative stereology shown in Figure 4. In addition, the morphology of the austenite phase ranged from elongated islands to an equiaxed form.

Only in DSSA, solution-treated at $1100^{\circ} \mathrm{C}$ for 240 minutes, Figure $2 \mathrm{~d}$, was the presence of the chi $(\chi)$ phase observed, precipitated in the contours of the ferrite/austenite ferrite/ ferrite grain. This phase is generally found along with the sigma $(\sigma)$ phase, in much smaller rates, however, making its identification difficult. This phase is fragile and unwanted in DSS, as it compromises the toughness, as well as the resistance to corrosion. The formation of the $\operatorname{chi}(\chi)$ phase occurs before the formation of the sigma $(\sigma)$ phase and the first is consumed for the formation of the sigma phase $\mathrm{e}^{6,25}$.

Table 2 presents the results of the semiquantitative microanalyses by energy-dispersive spectroscopy (EDS) of steels DSSA and DSSB in the conditions as received and solution-treated at $1100^{\circ} \mathrm{C}$, for 30,120 and 240 minutes, then cooled in water. The analyses were performed in regions $\mathrm{A}$ ( $\alpha$ phase) and B ( $\gamma$ phase), indicated in the micrographs. In all conditions, it was observed that the elements chromium and molybdenum are present in greater percentage in the ferrite phase, since they are ferritizing elements, and nickel is present in a greater percentage in the austenite phase, as it is an austeniting element. It should also be noted that there were no significant variations in the chromium, molybdenum and nickel content in the solubilized conditions.

Figure 4 and Table 3 show the results obtained from the quantitative stereology, in which the variations in the volumetric fractions from the ferrite and austenite phases of steels $\mathrm{A}$ and $\mathrm{B}$ are indicated, in the conditions as received and solution-treated for 30, 120 and 240 minutes.

A reduction in the volumetric fraction of the austenite phase was observed with an increase in solution treatment time. On the other hand, there was an increase in the volumetric fraction of the ferrite phase. This behavior occurs because of the transformation of the austenite phase into ferrite phase $(\gamma \rightarrow \alpha)$, when the temperature of the solution treatment is above $1050^{\circ} \mathrm{C}$ but below the solvus line, $1450^{\circ} \mathrm{C}$, there is a progressive increase in the ferrite phase, according to

Table 1. Nominal chemical composition of duplex stainless steels A and B (wt $\%)$.

\begin{tabular}{lccccccccc}
\hline Steel & $\mathrm{C}$ & $\mathrm{Mn}$ & $\mathrm{N}$ & $\mathrm{S}$ & $\mathrm{Si}$ & $\mathrm{Cr}$ & $\mathrm{Ni}$ & $\mathrm{Mo}$ & $\mathrm{Fe}$ \\
\hline DSS A & 0.015 & 1.97 & 0.17 & - & 0.45 & 23.0 & 5.5 & 3.15 & bal. \\
DSS B & 0.03 & 1.65 & - & 0.27 & 0.65 & 21.0 & 5.3 & - & bal. \\
\hline
\end{tabular}




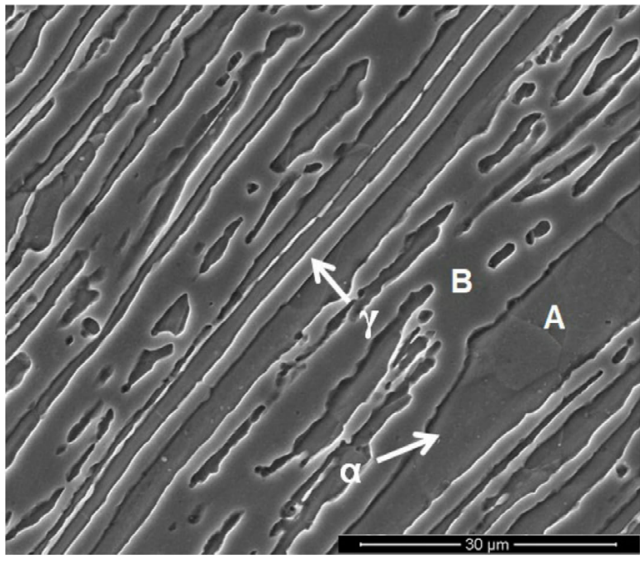

(a)

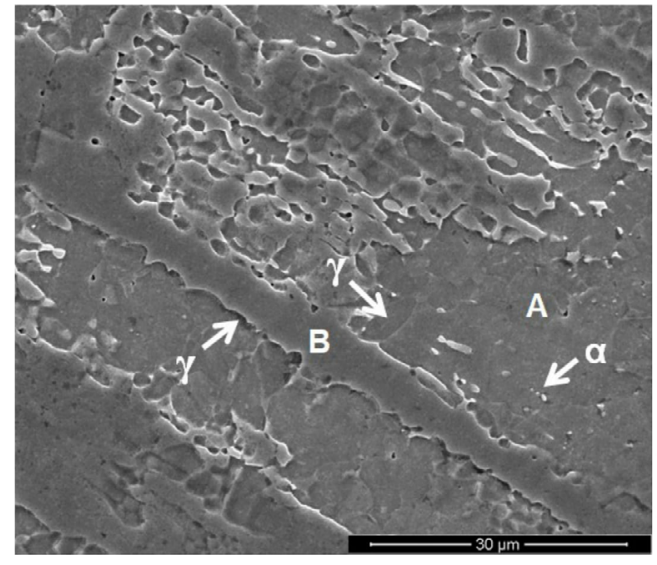

(b)

Figure 1. Micrographs obtained by SEM in the condition as-received. (a) DSSA; (b) DSSB .

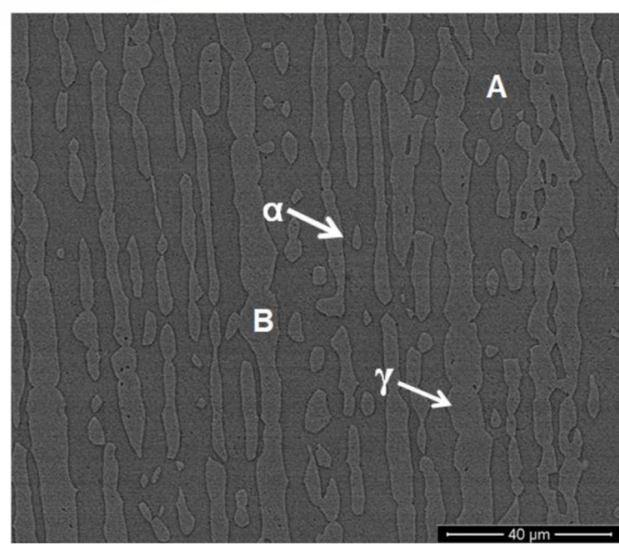

(a)

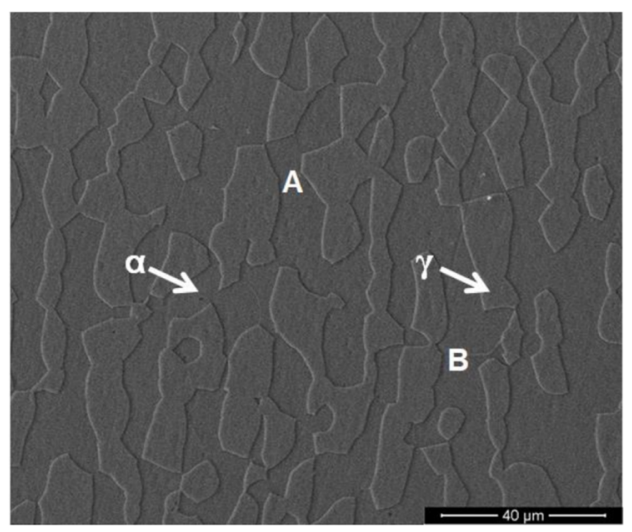

(c)

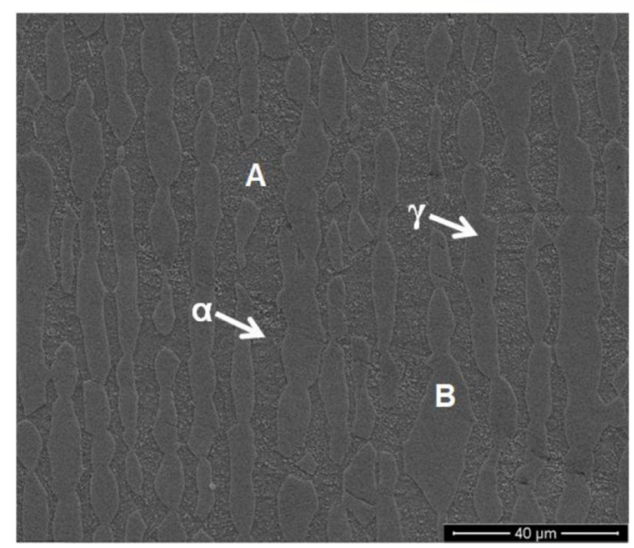

(b)

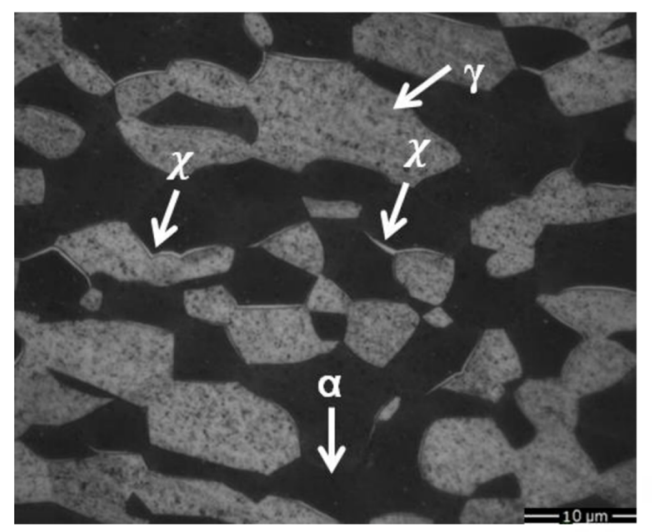

(d)

Figure 2. Micrographs of DSSA solution-treated at $1100^{\circ} \mathrm{C}$ and cooled in water. (a) Solubilized for 30 min by SEM; (b) Solubilized for $120 \mathrm{~min}$ by SEM; (c) Solubilized for $240 \mathrm{~min}$ by SEM; (d) Solubilized for $240 \mathrm{~min}$ by OM.

Vijayalakshmi, Muthupandi and Jayachitra ${ }^{24}$, also observed in this work, as shown in Figures 2 and 3.

Figure 5 shows the XRD of the duplex stainless steels A and $\mathrm{B}$, in the conditions as received and solubilized. In the conditions as received, the steels exhibited only the ferrite and austenite phases, corroborating the results presented in Figure 1. In the conditions of the solubilized steels A and $\mathrm{B}$, the presence of the ferrite and austenite phases can be observed by the spectra, for both steels and in all solutiontreated conditions. Only in DSSA solubilized for 240 minutes, 


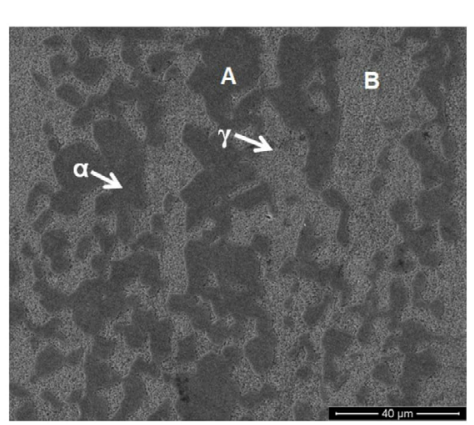

(a)

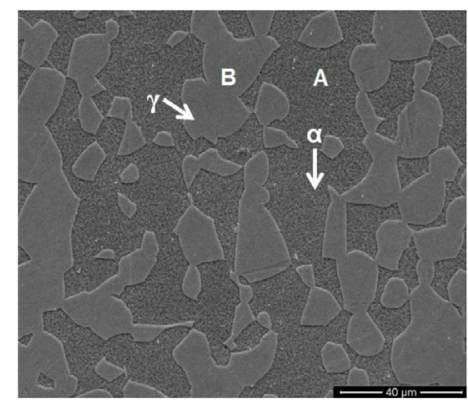

(c)

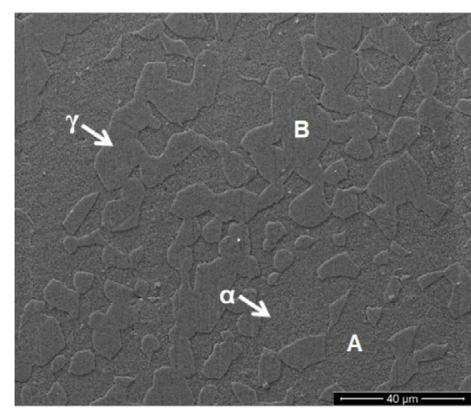

(b)

Figure 3. Micrographs of DSSB solution-treated at $1100^{\circ} \mathrm{C}$ and cooled in water. (a) Solubilized for 30 min by SEM; (b) Solubilized for $120 \mathrm{~min}$ by SEM; (c) Solubilized for $240 \mathrm{~min}$ by SEM.

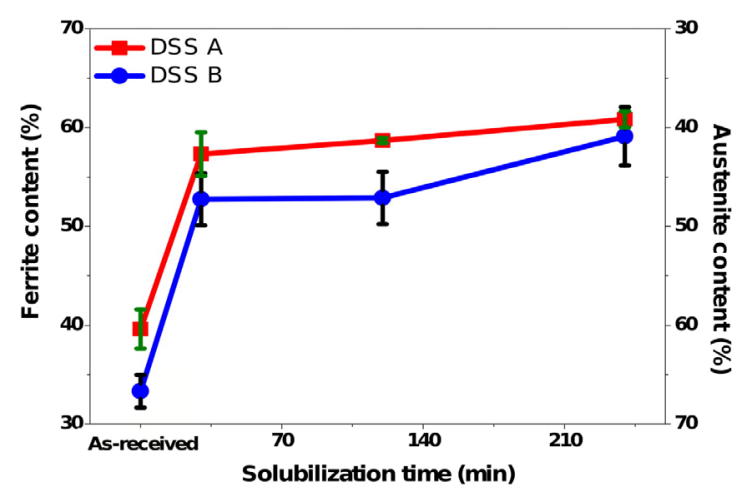

Figure 4. Volumetric fractions of the ferrite and austenite phases of duplex stainless steels $\mathrm{A}$ and $\mathrm{B}$ in the conditions as-received and solubilized for $30 \mathrm{~min}, 120 \mathrm{~min}$ and $240 \mathrm{~min}$.

a discreet peak referring to the chi $(\chi)$ phase was observed, also shown in Figure 2d.

Table 4 shows the microhardness (HV) values for the ferrite and austenite phases of the duplex stainless steels A and $\mathrm{B}$, both in the conditions as received and solubilized. It was observed that the austenite phase exhibited greater microhardness values in relation to the ferrite phase, in both steels, except steel A solubilized for 240 minutes. This fact can be a result of the presence of the chi $(\chi)$ phase, in the contours of the ferrite/austenite and ferrite/ferrite phase grains, leading to an increase in the microhardness in the ferrite phase. The larger microhardness values in the ferrite phase of DSSA compared to DSSB occur because of the higher content of the ferritizing alloy elements (chromium and molybdenum), present in the ferrite phase (observed by EDS in Table 2), that increase microhardness. This fact was also observed by Shrikrishna and Sathiya (2015).

Figure 6a shows the DSC curves for the duplex stainless steels $\mathrm{A}$ and $\mathrm{B}$, and endothermic peaks are observed at temperatures of $216.6^{\circ} \mathrm{C}$ and $214.4^{\circ} \mathrm{C}$, respectively, relating to the loss of molecular water. The exothermic peak at the temperatures of $712.9^{\circ} \mathrm{C}$ (DSSA) and $672.6^{\circ} \mathrm{C}$ (DSSB) occurs because of the transformation of the austenite phase into ferrite, and/or by the dissolution of precipitates (carbides and nitrides), a result also observed by Petrovič et al. (2012) while studying the effect of the cooling rates in the microstructure of a duplex stainless steel. It was also observed that the duplex stainless steels $\mathrm{A}$ and $\mathrm{B}$ exhibited an exothermic peak at $500^{\circ} \mathrm{C}$ and, according to Paulraj and Garg (2015), this peak is associated with the decomposition of the ferrite $(\alpha)$ phase into ferrite alpha line $\left(\alpha\right.$ ) rich in iron and in chromium ${ }^{6}$.

In Figure $6 \mathrm{~b}$, regarding the TG curves for DSSA, a gain in mass of $1.27 \%$ can be observed as the temperature is raised, due to the oxidation suffered by the steel during heating. However, in the range of $600-1000^{\circ} \mathrm{C}$ there was a loss of mass of $0.89 \%$ because of the dissolution of carbides and nitrides. DSSB exhibited a behavior similar to that of DSSA and, as shown in Figure 6 b, there was a gain in mass of $0.57 \%$ as the temperature was raised to around $428^{\circ} \mathrm{C}$, followed by a mass 
Table 2. Semiquantitative by EDS of duplex stainless steels A and B (wt $\%)$.

\begin{tabular}{|c|c|c|c|c|c|c|c|}
\hline Steel & $\begin{array}{l}\text { Solution- } \\
\text { treated (min) }\end{array}$ & Phases & $\mathrm{Fe}$ & $\mathrm{Cr}$ & $\mathrm{Ni}$ & Mo & $\mathrm{Mn}$ \\
\hline \multirow[t]{8}{*}{ DSS A } & As-received & $\alpha(\mathrm{A})$ & 62.52 & 24.14 & 3.96 & 3.18 & 1.97 \\
\hline & & $\gamma(\mathrm{B})$ & 64.01 & 20.77 & 6.75 & 2.72 & 2.09 \\
\hline & 30 & $\alpha(\mathrm{A})$ & 65.15 & 24.23 & 4.41 & 4.30 & 1.90 \\
\hline & & $\gamma(\mathrm{B})$ & 67.10 & 21.49 & 6.86 & 2.50 & 2.04 \\
\hline & 120 & $\alpha(\mathrm{A})$ & 64.45 & 25.21 & 4.43 & 3.89 & 2.02 \\
\hline & & $\gamma(\mathrm{B})$ & 66.77 & 21.55 & 7.13 & 2.54 & 2.01 \\
\hline & 240 & $\alpha(\mathrm{A})$ & 63.51 & 24.68 & 4.65 & 5.11 & 2.06 \\
\hline & & $\gamma(\mathrm{B})$ & 65.34 & 21.16 & 6.72 & 4.01 & 2.78 \\
\hline \multirow[t]{8}{*}{ DSS B } & As-received & $\alpha(\mathrm{A})$ & 71.44 & 24.87 & 3.33 & - & - \\
\hline & & $\gamma(\mathrm{B})$ & 70.51 & 22.14 & 5.18 & - & - \\
\hline & 30 & $\alpha(\mathrm{A})$ & 69.76 & 24.94 & 3.74 & - & 1.55 \\
\hline & & $\gamma(\mathrm{B})$ & 71.82 & 20.87 & 5.48 & - & 1.83 \\
\hline & 120 & $\alpha(\mathrm{A})$ & 70.73 & 22.61 & 4.98 & - & 1.67 \\
\hline & & $\gamma(\mathrm{B})$ & 72.28 & 20.99 & 5.09 & - & 1.65 \\
\hline & 240 & $\alpha(\mathrm{A})$ & 70.19 & 24.78 & 3.56 & - & 1.47 \\
\hline & & $\gamma(\mathrm{B})$ & 72.40 & 20.81 & 5.32 & - & 1.47 \\
\hline
\end{tabular}

Table 3. Volumetric fraction of the ferrite phase of duplex stainless steels A and B.

\begin{tabular}{lcc}
\hline Steel & Solution-treated $(\mathrm{min})$ & Ferrite phase $(\%)$ \\
\hline DSS A & As-received & $39.63 \pm 1.98$ \\
& 30 & $57.32 \pm 2.20$ \\
& 120 & $58.70 \pm 0.25$ \\
& 240 & $60.85 \pm 0.81$ \\
\hline DSS B & As- received & $33.32 \pm 1.66$ \\
& 30 & $52.75 \pm 2.63$ \\
& 120 & $52.88 \pm 2.64$ \\
& 240 & $59.12 \pm 2.95$ \\
\hline
\end{tabular}

loss of $0.495 \%$ that started at around $714^{\circ} \mathrm{C}$. Subsequently, there was a gain in mass of $0.55 \%$, up to the temperature of $1000^{\circ} \mathrm{C}$. The mass loss is associated with the dissolution of carbides and nitrides and the mass gain is associated with oxidation in DSSB.

The open circuit potentials (OCP) of steels A and B, in a solution of lithium chloride at a concentration of 120,000 ppm of $\mathrm{Cl}^{-}$, at room temperature, are shown in Figure 7 and Table 5. All tests were triplicated to check the repeatability of the results. The OCP curve towards more positive potentials suggests the formation of a passive film on the metal surface, and the reduction of potential suggests a generalized corrosion, while potentials practically constant over time suggest that the passive film formed over the surface is stable and adherent to $\mathrm{it}^{12}$.

In Figures $7 \mathrm{a}$ and $7 \mathrm{~b}$ it was observed that duplex stainless steels A and B exhibited a behavior in which the potentials shifted to positive values over the time of the test, except for
DSSA in the conditions as received, in which the potentials were practically constant over time.

The cyclic potential dynamic polarization (PPC) curves are presented in Figure 8, and Table 6 presents the electrochemical parameters: Ecorr (corrosion potential), Epit (pitting potential), Eprot (protective potential) and Ipass (passive current density), obtained from the PPC curves.

The polarization curves of the duplex stainless steels A and $\mathrm{B}$, indicated in Figures $8 \mathrm{a}$ and $8 \mathrm{~b}$, exhibited two passive regions, as Figure $8 \mathrm{c}$ shows in detail. This behavior is due to the duplex microstructure, composed of ferritic and austenitic phases.

Chromium and molybdenum stabilize and passivate the ferrite phase, while in the austenite phase they possess only the role of passivation. The effect of these elements in relation to the resistance to pit corrosion is greater in the austenite phase than in the ferrite phase. For this reason, the ferrite phase undergoes passivation more quickly than the austenite phase, associated with the first passive region of the polarization curve. The second passive region of the polarization curve is associated with the passivation of the austenite phase $\mathrm{e}^{28-29}$.

Oscillations in the density of the anodic currents were observed in the polarization curves of steels DSSA and DSSB, in the conditions as received and solubilized for 120 minutes and, according to Szklarska-Smialowska (2002), they are related to the consecutive formation and repassivation of micropits. These pits are called metastable. They grow and repassivate in a few seconds and are occasionally formed below the pitting potential and during the induction time for the development of a stable pitting ${ }^{30-34}$. 


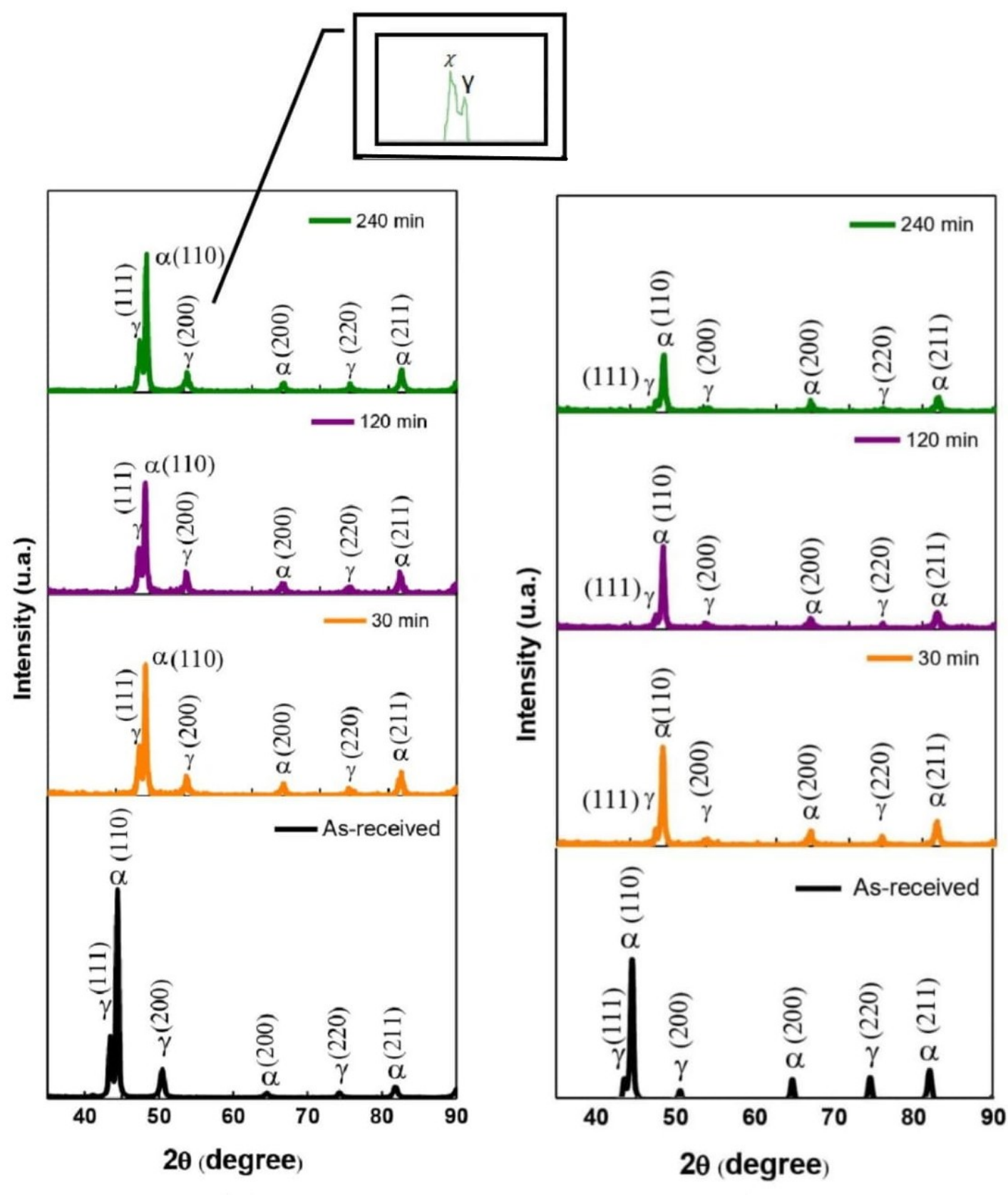

(a)

(b)

Figure 5. XRD spectra of duplex stainless steels under conditions as received and solubilized at $1100^{\circ} \mathrm{C}$ for $30 \mathrm{~min}, 120 \mathrm{~min}$ and 240 min. (a) Duplex stainless steel A; (b) Duplex stainless steel B.

It was observed that DSSA, for all conditions of solution treatment studied, exhibited lower corrosion potential values $\left(\mathrm{E}_{\text {corr }}\right)$ compared to DSSB. In other words, the anodic segment began at lower potentials, as shown in Figure 9a. The $\mathrm{E}_{\text {corr }}$ obtained by the OCP curves and presented in Table 5 showed higher values for both steels than those obtained by the PPC curves and presented in Table 6. This difference can be mainly attributed to the incomplete stabilization of the passive layer developed on the surface of the steels and to the cathodic polarization undergone before reaching the complete stabilization of the open circuit potential. 
Table 4. Microhardness (HV) values of the duplex stainless steels A and B.

\begin{tabular}{lccc}
\hline Steel & Phase & $\begin{array}{c}\text { Microhardness } \\
(\text { HV) }\end{array}$ & $\begin{array}{c}\text { Solution- } \\
\text { treated (min) }\end{array}$ \\
\hline DSS A & $\alpha$ & $247 \pm 3.40$ & As-received \\
& $\gamma$ & $256 \pm 5.80$ & \\
& $\alpha$ & $235 \pm 4.91$ & 30 \\
& $\gamma$ & $244 \pm 3.50$ & \\
& $\alpha$ & $243 \pm 3.49$ & 120 \\
& $\gamma$ & $246 \pm 4.04$ & \\
& $\alpha$ & $240 \pm 3.25$ & 240 \\
\hline DSS B & $\gamma$ & $234 \pm 3.08$ & \\
& $\alpha$ & $239 \pm 3.80$ & As-received \\
& $\gamma$ & $256 \pm 7.50$ & \\
& $\alpha$ & $218 \pm 2.19$ & 30 \\
& $\gamma$ & $235 \pm 1.89$ & \\
& $\alpha$ & $238 \pm 0.90$ & 120 \\
& $\gamma$ & $247 \pm 1.89$ & \\
& $\alpha$ & $202 \pm 1.50$ & 240 \\
$\gamma$ & $228 \pm 4.07$ & \\
\hline
\end{tabular}

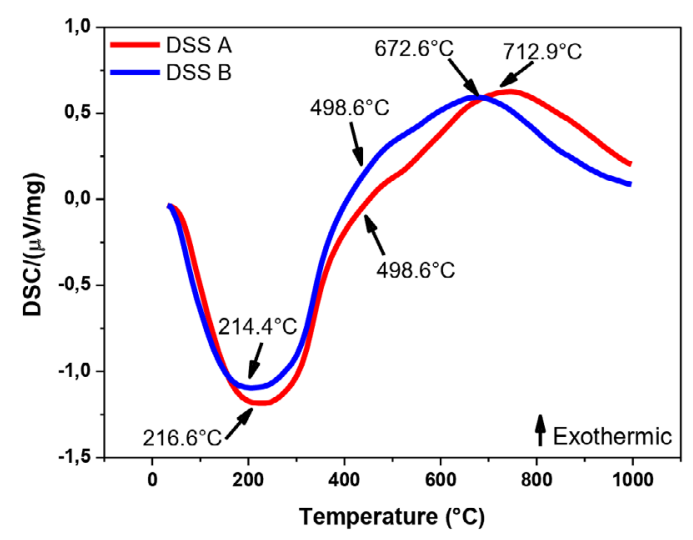

(a)
Figure $9 \mathrm{~b}$ shows the variation in the pitting potential $\left(\mathrm{E}_{\mathrm{pit}}\right)$ as a function of solution treatment time. An increase in pit potential was observed when compared to the respective steels in the conditions received. This demonstrates a beneficial effect in the resistance to pitting corrosion.

The density of the passivation current (Ipass) indicates the start speed of the passivation process and corresponds to the value from which the polarization curve presents a region with an approximately stable current as the potential increases. The passivation potentials for steels $\mathrm{A}$ and $\mathrm{B}$ in the conditions as received were $2.7 \times 10^{-4}$ and $8.3 \times 10^{-6} \mathrm{~A} / \mathrm{cm}^{2}$, respectively, indicating that the passivation process in DSSB began first. This result is due to the greater austenite phase content compared to the ferrite phase, in DSSB (shown in the quantitative stereology analysis, Table 3) because, despite the absence of molybdenum in its chemical composition, the austenite phase fosters passivation.

After solution-treated for 120 minutes, DSSA exhibited the lowest passivation current $\left(\mathrm{I}_{\text {pass }}=6.6 \times 10^{-7} \mathrm{~A} / \mathrm{cm}^{2}\right)$ compared to the other conditions for the same steel and had a similar

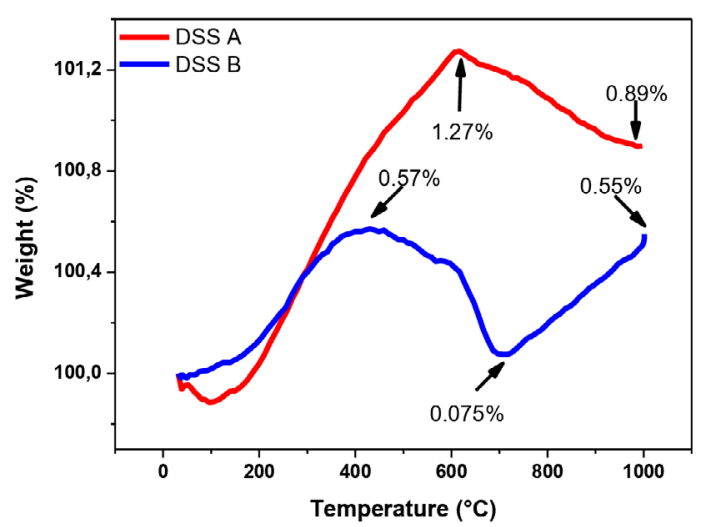

(b)

Figure 6. Thermal analysis for duplex stainless steels A and B. (a) DSC curves; (b) TG curves.

Table 5. Open circuit potential of duplex stainless steels A and B, in solution of lithium chloride at concentration of 120,000 ppm of $\mathrm{Cl}$ - at $25^{\circ} \mathrm{C}$

\begin{tabular}{lcc}
\hline Steel & Solution-treated (min) & E (mV/SCE) \\
\hline DSS A & As-received & -250 \\
& 30 & -168 \\
& 120 & -115 \\
\hline DSS B & 240 & -178 \\
& As-received & -180 \\
& 30 & -167 \\
& 120 & -147 \\
\hline
\end{tabular}




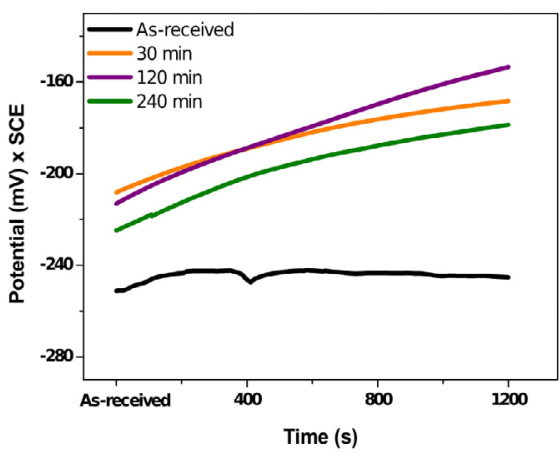

(a)

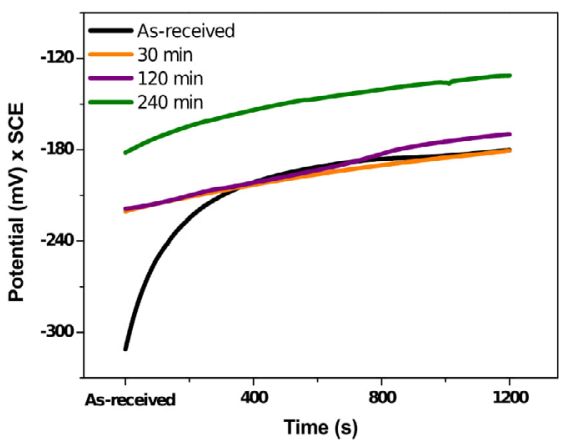

(b)

Figure 7. Evolution of the open circuit potential in solution of lithium chloride at a concentration of $120,000 \mathrm{ppm}$ of Cl. (a) DSSA; (b) DSSB.

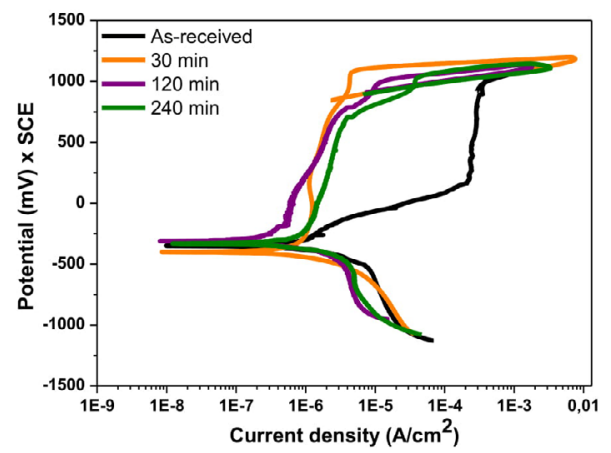

(a)

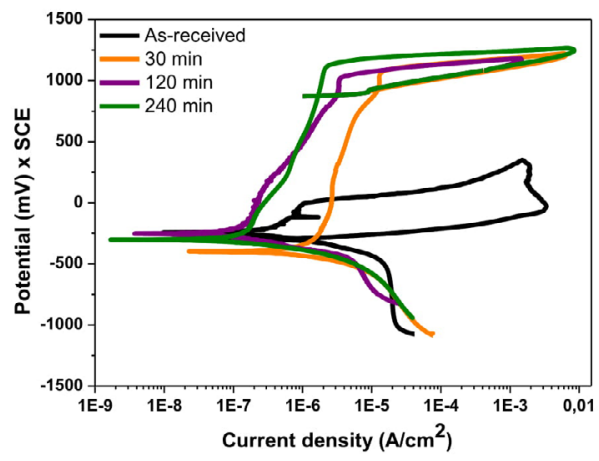

(b)

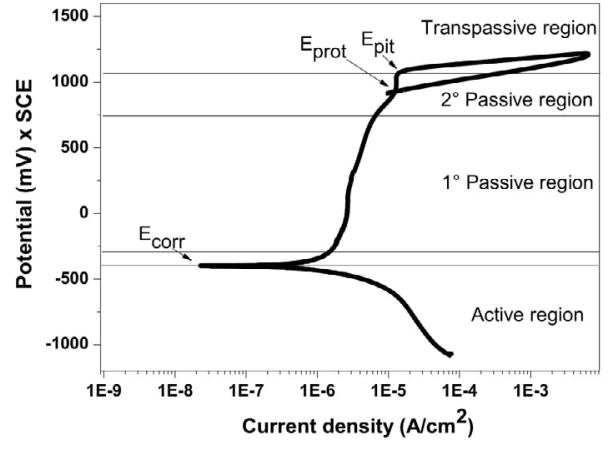

(c)

Figure 8. Cyclic potentiodynamic polarization curves in solution of lithium chloride at a concentration of 120,000 ppm of Cl-. (a) DSSA; (b) DSSB; (c) In detail: main regions and electrochemical parameters - DSSB-solubilized for $120 \mathrm{~min}$. 
Table 6. Electrochemical parameters of duplex stainless steels A and B, in solution of lithium chloride at concentration of $120,000 \mathrm{ppm}$ of $\mathrm{Cl}-$ at $25^{\circ} \mathrm{C}$.

\begin{tabular}{|c|c|c|c|c|c|}
\hline Steel & $\begin{array}{l}\text { Solution-treated } \\
\text { (min) }\end{array}$ & $\frac{E_{\text {corr }}}{(\mathrm{mV} / \mathrm{SCE})}$ & $\begin{array}{c}\text { Epit } \\
(\mathrm{mV} / \mathrm{SCE})\end{array}$ & $\underset{(\mathrm{mV} / \mathrm{SCE})}{\mathrm{E}_{\text {prot }}}$ & $\mathrm{I}_{\text {pass }}\left(\mathrm{A} / \mathrm{cm}^{2}\right)$ \\
\hline \multirow[t]{4}{*}{ DSS A } & As-received & -349 & 998 & 989 & $2.7 \times 10^{-4}$ \\
\hline & 30 & -395 & 1081 & 883 & $1.4 \times 10^{-6}$ \\
\hline & 120 & -318 & 1050 & 945 & $6.6 \times 10^{-7}$ \\
\hline & 240 & -383 & 1035 & 971 & $1.9 \times 10^{-6}$ \\
\hline \multirow[t]{4}{*}{ DSS B } & As-received & -242 & 144 & -243 & $8.3 \times 10^{-6}$ \\
\hline & 30 & -392 & 1071 & 930 & $2.8 \times 10^{-6}$ \\
\hline & 120 & -262 & 1022 & 881 & $2.2 \times 10^{-7}$ \\
\hline & 240 & -273 & 1139 & 876 & $6.9 \times 10^{-7}$ \\
\hline
\end{tabular}

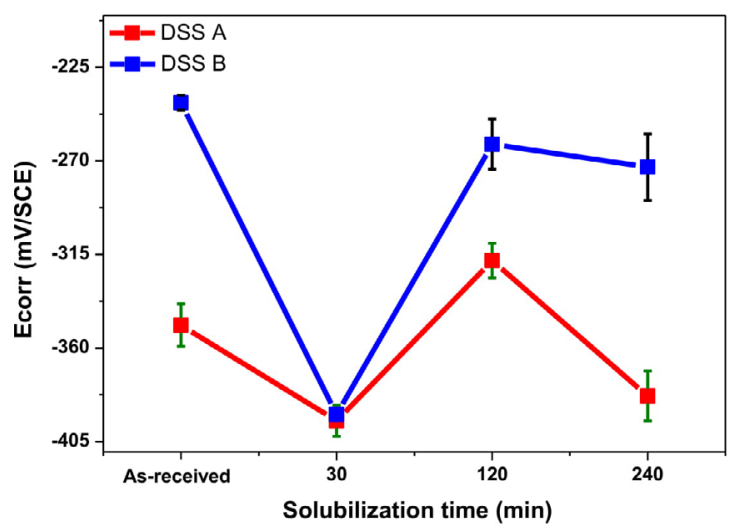

(a)

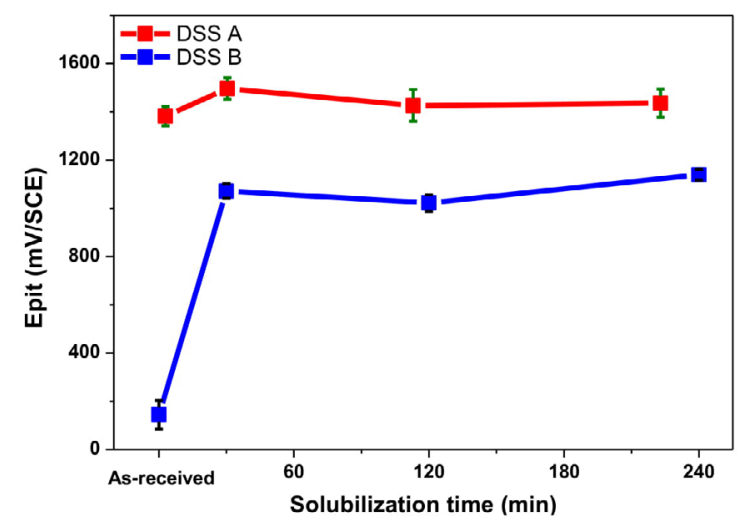

(b)

Figure 9. Effect of the solubilization time of duplex stainless steels A and B. (a) Corrosion potential; (b) Pitting potential.

behavior to DSSB after solution-treated for 120 minutes $\left(\mathrm{I}_{\text {pass }}=2.2 \times 0^{-7} \mathrm{~A} / \mathrm{cm}^{2}\right)$ and 240 minutes $\left(\mathrm{I}_{\text {pass }}=6.9 \times 10^{-7} \mathrm{~A} / \mathrm{cm}^{2}\right)$.

The protection potential (Eprot) indicates the potential below which the formed pits undergo passivation, that is, the pits become inactive and between the pitting $\left(\mathrm{E}_{\mathrm{pit}}\right)$ and protection $\left(\mathrm{E}_{\text {prot }}\right)$ potentials there is the growth only in the already nucleated pits. The protection potential is determined at the point where the polarization curve is intercepted after the reversal of the scanning of the potential. The protection potential for DSSB in the conditions as received and after solution-treated for 30, 120 and 240 minutes were -243, 930,881 and $876 \mathrm{mV}$, respectively, showing that there was a considerable increase in $\mathrm{E}_{\text {prot, }}$ and indicating that the conditions employed in the solution treatment were efficient.

\section{Conclusion}

The duplex stainless steels A and B in the conditions as received exhibited microstructures composed of ferrite and austenite phases, with volumetric fractions of the austenite phase superior to those of the ferrite phase. The solution treatment fostered a microstructure with a ferritic matrix and with austenite lamellas, in steels DSSA and DSSB. However, in the DSSA solubilized for 240 minutes, the presence of the intermetallic chi $(\chi)$ phase was also observed. The increase in solution treatment time fostered an increase in the volumetric fraction of the ferrite phase in both steels. The austenite phase exhibited higher rates of microhardness in relation to the ferrite phase, in both steels, after solution-treated, except for DSSA solubilized for 240 minutes, due to the presence of the chi $(\chi)$ phase in the contours of the ferrite/austenite and ferrite/ ferrite phase grains. The polarization curves of DSSA and DSSB present two passive regions, one associated with the passivation of the ferrite phase and the other associated with the austenite phase. Small fluctuations in the anodic current density in the polarization curves of steels DSSA and DSSB solubilized for 120 minutes were the result of the nucleation and repassivation of metastable pits during the corrosion process. The solution treatment contributed positively to both steels in the resistance to pitting corrosion, especially in DSSB, when compared to the steels in the conditions as received. The solution treatment at $1100^{\circ} \mathrm{C}$ for 120 minutes with cooling in water, for steels DSSA and DSSB, provided good resistance to pitting corrosion and the development of 
a passivating film in a lithium chloride medium $(120,000$ ppm of chloride ions).

\section{Acknowledgment}

The authors thank the Brazilian research funding agencies FAPEMIG, CNPq, FINEP and CAPES for the financial support.

\section{References}

1. Guo Q, Liu J, Yu M, Li S. Effect of passive film on mechanical properties of martensitic stainless steel $15-5 \mathrm{PH}$ in a neutral $\mathrm{NaCl}$ solution. Applied Surface Science: A. 2015;327:313-320.

2. Dille J, Areiza MCL, Tavares SSM, Pereira GR, Almeida LH, Rebello JMA. Microstructural evolution during aging at $800^{\circ} \mathrm{C}$ and its effect on the magnetic behavior of UNS S32304 lean duplex stainless steel. Journal of Magnetism and Magnetic Materials. 2017;426:102-107.

3. Verma J, Taiwade RV. Effect of welding processes and conditions on the microstructure, mechanical properties and corrosion resistance of duplex stainless steel weldments - A Review. Journal of Manufacturing Processes. 2017;25:134-152.

4. Bonollo F, Tiziani A, Ferro P. Welding processes microstructural evolution and final properties of duplex and super duplex stainlees steels. In: Alvares-Armas I, Degallaix-Moreuli S, editors. Duplex Stainless Steels. London: ISTE Ltd and John Wiley \& Sons; 2009. p. 141-159.

5. Armas IA, Mareuil SD. Duplex Stainless Steel. In: Liljas M, Sjoholm F. Applications. Grã Bretanha: ISTE Ltd; 2009. p. 1-433.

6. Paulraj P, Garg R. Effect of intermetallic phases on corrosion behavior and mechanical properties of duplex stainless steel and super-duplex stainless steel. Advances in Science and Technology Research Journal. 2015;9(27):87-105.

7. Ha HY, Jang MH, Lee TH, Moon J. Interpretation of the relation between ferrite fraction and pitting corrosion resistance of commercial 2205 duplex stainless steel. Corrosion Science. 2014;89:154-162.

8. Han J, Li H, Barbaro F, Jiang L, Zhu Z, Xu H, et al. Precipitation and impact toughness of $\mathrm{Nb}-\mathrm{V}$ stabilised $18 \mathrm{Cr}-2 \mathrm{Mo}$ ferritic stainless steel during isothermal aging. Materials Science and Engineering: A. 2014;612:63-70.

9. Jinlong L, Liang T, Wang C, Guo T. Influence of sensitization on passive films in AISI 2205 duplex stainless steel. Journal of Alloys and Compounds. 2016;658:657-662.

10. Chail G, Kangas P. Super and hyper duplex stainless steels: structures, properties and applications. Procedia Structural Integrity. 2016;2:1755-1762.

11. Xu D, Xia J, Zhou E, Zhang D, Li H, Yang C, et al. Accelerated corrosion of 2205 duplex stainless steel caused by marine aerobic Pseudomonas aeruginosa biofilm. Bioelectrochemistry. 2017;113:1-8.

12. Ma H, Qin G, Geng P, Li F, Meng X, Fu B. Effects of post weld heat treatment on friction welded duplex stainless steel joints. Journal of Manufacturing Processes. 2016;227:24-33.
13. Jinlong LV, Tongxiang L, Chen W, Limin D. Effect of ultrafine grain on tensile behaviour and corrosion resistance of the duplex stainless steel. Materials Science and Engineering: C, Materials for Biological Applications. 2016;62:558-563.

14. Jinlong LV, Tongxiang L, Chen W, Limin D. Comparison of corrosion properties of passive films formed on coarse grained and ultrafine grained AISI 2205 duplex stainless steels. Journal of Electroanalytical Chemistry. 2015;757:263-269.

15. Garcia MA, López-Morelos VH, Gonzáles-Sánches J, GarcíaHernándes R, Dzib-Pérez L, Curiel-López FF. Effect of electromagnetic interaction during fusion welding of AISI 2205 duplex stainless steel on the corrosion resistance. Applied Surface Science. 2017;396:1187-1200.

16. Kashiwar A, Vennela NP, Kamath SL, Khatirkar RK. Effect of solution annealing temperature on precipitation in 2205 duplex stainless steel. Materials Characterization. 2012;74:55-63.

17. Lacerda JC, Cândido LC, Godefroid LB. Effect of volume fraction of phases and precipitates on the mechanical behavior of UNS S31803 duplex stainless steel. International Journal of Fatigue. 2015;74:81-87.

18. Rezende SC. Estudo do Mo na microestrutura e na resistência à corrosão em aço inoxidável duplex [dissertation]. Poços de Caldas: Mestrado em Ciência e Engenharia de Materiais Federal University of Alfenas; 2018. https://bdtd.unifal-mg.edu. br:8443/bitstream/tede/1255/5/Disserta\%C3\%A7\%C3\%A3o StephaniaCapellariDeRezende_2018_PPGCEM.pdf

19. Forgas JA, Otubo J, Magnabosco R. Ferrite Quantification Methodologies for Duplex Stainless Steel. Journal of Aerospace Technology and Management. 2016;8(3):357-362.

20. Cronemberger MER, Nakamatsu S, Rovere CAD, Kuri SE, Mariano NA. Effect of Cooling Rate on the Corrosion Behavior of as-Cast SAF 2205 Duplex Stainless Steel After Solution Annealing Treatment. Materials Research. 2015;18(Suppl 2):138-142

21. Brooks EK, Brooks RP, Ehrensberger MT. Effects of simulated inflammation on the corrosion of $316 \mathrm{~L}$ stainless steel. Materials Science and Engineering: C. 2017;71:200-205.

22. Silva R, Baroni LFS, Silva MBR, Afonso CRM, Kuri SE, Rovere $\mathrm{CAD}$. Effect of thermal aging at $475^{\circ} \mathrm{C}$ on the properties of an duplex stainless steel 2101. Materials Characterization. 2016;114:211-217.

23. Pohl M, Storz O, Glogowski T. Effect of intermetallic precipitation on the properties of duplex stainless steel. Materials Characterization. 2007;58(1):65-71.

24. Vijayalakshmi K, MuthupandinV, Jayachitra R. Influence of heat treatment on the microstructure, ultrasonic attenuation and hardness of SAF 2205 duplex stainless steel. Materials Science and Engineering: A. 2011;529:447-451.

25. Escriba DM, Materna-Morris E, Plaut RL, Padilha AF. Intermetallic phase precipitation in duplex stainless steels during high temperature exposition. Materials Science Forum. 2010;636-637:478-484

26. Makhdoom MA, et al. Microstructural and electrochemical behavior of 2205 Duplex Satailess Steel Weldments. Surfaces and Interfaces. 2017;9:189-195. 
27. Alphonsa J, Raja VS, Mukherjee S. Study of plasma nitriding and nitrocarburizing for higher corrosion resistance and hardness of 2205 duplex stainless steel. Corrosion Science. 2015;100:S0010.

28. Petrovič, DS, Pirnat M, Klančnik G, Mrvar P, Medved J. The effect of cooling rate on the solidification and microstructure evolution in duplex stainless steel. Journal of Thermal Analysis and Calorimetry. 2012;109(3):1185-1191.

29. Wang S, Ma Q, Li Y. Characterization of microstructure, mechanical properties and corrosion resistance of dissimilar welded joint between 2205 duplex stainless steel and $16 \mathrm{MnR}$. Materials \& Design. 2011;32:831-837.

30. Yoo YA, Choi YS, Kim JG, Park YS. Effects of Ce, La and $\mathrm{Ba}$ addition on the electrochemical behavior of super duplex stainless steels. Corrosion Science. 2010;52(4):1123-1129.
31. Kim ST, Jang SH, Lee IS, Park YS. Effects of solution heattreatment and nitrogen in shielding gas on the resistance to pitting corrosion of hyper duplex stainless steel welds. Corrosion Science. 2011;53(5):1939-1947.

32. Szklarska-Smialowska Z. Mechanism of pit nucleation by electrical break down of the passive film. Corrosion Science. 2002;44(5):1143-1149.

33. Park KJ, Kwon HS. Effects of Mn on the localized corrosion behavior of Fe-18Cr alloys. Electrochimica Acta. 2010;55(9):3421-3427.

34. Tang YM, Zuo Y, Zhao XH. The metastable pitting behavior of mild steel in bicarbonate and nitrite solutions containing Cl-. Corrosion Science. 2008;50(4):984-994. 